\title{
Effects of Some Organic Acids on the Dark Germination of Tobacco Seed
}

\author{
by Noriko TakahaShi*, Takeko MoRoo*, Tohru HaShimoto** \\ and Toshio YAMAKI***
}

\section{Received October 11, 1961}

In our previous experiments ${ }^{1,2)}$, we found that the rates of gibberellin induced dark germination changed remarkably by the lengthening of the storage period of the tobacco seed, that several inorganic compounds seemed to accelerate the dark germination inducing action of gibberellin in different ways, and that the effect of gibberellin on the seed of short storage length was promoted at two or three $\mathrm{pH}$ ranges, i.e. at around $\mathrm{pH} 2.0$ to 2.5 , and from $\mathrm{pH} 4.7$ to 5.5 in all the cases of previous experiments, and at one more specific $\mathrm{pH}$ range at around 4.0 in the presence of phosphate in the germination bed; in the presence of several inorganic nitrogenous compounds like potassium nitrate, ammonium chloride, the seed also germinated well at around $\mathrm{pH}$ 3.0. When the storage length of the seed is long, however, the accelerating effect of gibberellin on the dark germination was increased only at $\mathrm{pH}$ 2.0 to 2.5 , and decreased at around $\mathrm{pH} 4.7$ to 5.5 .

Hashimoto and $\mathrm{Yamaki}^{2)}$ and Hashimoto ${ }^{4)}$ also reported the dark germination inducing action of ammonium salts of several carboxylic acids. In the present paper, are reported the results of the experiments concerning the effects of ammonium or potassium salts of several organic acids on the dark germination of tobacco seed on the germination beds of various $\mathrm{pH}$ : on the one hand those dealing with the effect of these organic acids on the dark germination inducing action of gibberellin, and on the other hand those dealing with the dark germination inducing action of these organic acids themselves.

Material and Methods are same as those in the previous papers ${ }^{1,2)}$.

\section{Results}

\section{Effect of malic acid on the dark germination:}

Malic acid was added to the germination bed at final concentration of $M / 100$ in the presence or absence of $10 \mathrm{ppm}$ gibberellin. $\mathrm{pH}$ of the germination bed was adjusted with this acid and $\mathrm{NH}_{4}(\mathrm{OH}$ or $\mathrm{KOH}$, with the intervals of $\mathrm{pH} 0.2$. The storage length of the seed used was 15 and 27 months in the experiments using malic acid and $\mathrm{NH}_{4} \mathrm{OH}$ as $\mathrm{pH}$ adjusters, and 15 months in the experiments using malic acid and $\mathrm{KOH}$.

The results of the former experiments are shown in Fig. 1 and those of the latter in Fig. 2.

From these figures, the following results are observed.

1) In the presence of malic acid and $\mathrm{NH}_{4} \mathrm{OH}$ the dark germination of 15 months

* Physiological Laboratory, Japan Women's University, Bunkyo-ku Tokyo, Japan.

** Biological Laboratory, Musashi University, Nerima-ku, Tokyo, Japan.

*** Biological Institute, College of General Education, University of Tokyo, Komaba, Meguro-ku, Tokyo, Japan. 


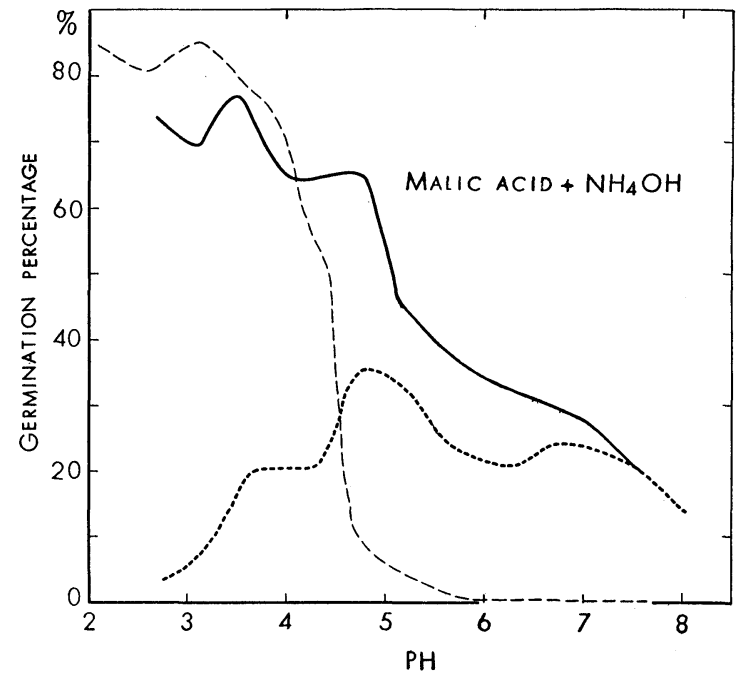

Fig. 1. Effect of malic acid on the dark germination of tobacco seed. $\mathrm{pH}$ was adjusted with $\mathrm{NH}_{4} \mathrm{OH}$. -; 15 months stored seed, in presence of $10 \mathrm{ppm}$ gibberellin, - - -; 27 months stored seed, in presence of $10 \mathrm{ppm}$ gibberellin, ........ 15 months stored seed, in absence of gibberellin. No dark germination of 27 months stored seed was observed on the germination beds of varing $\mathrm{pH}$, being adjusted with malic acid and $\mathrm{NH}_{4} \mathrm{OH}$. No dark germination was observed on the control germination bed wetted with distilled water and/or $10 \mathrm{ppm}$ gibberellin.

Fig. 2. Effect of malic acid on the dark germination of tobacco seed. $\mathrm{pH}$ was adjusted with $\mathrm{KOH}$. -; 15 months stored seed, in presence of $10 \mathrm{ppm}$ gibberellin, ..... 15 months stored seed, in absence of gibberellin. No dark germination was observed in the control germination bed wetted with distilled water and/or $10 \mathrm{ppm}$ gibberellin.

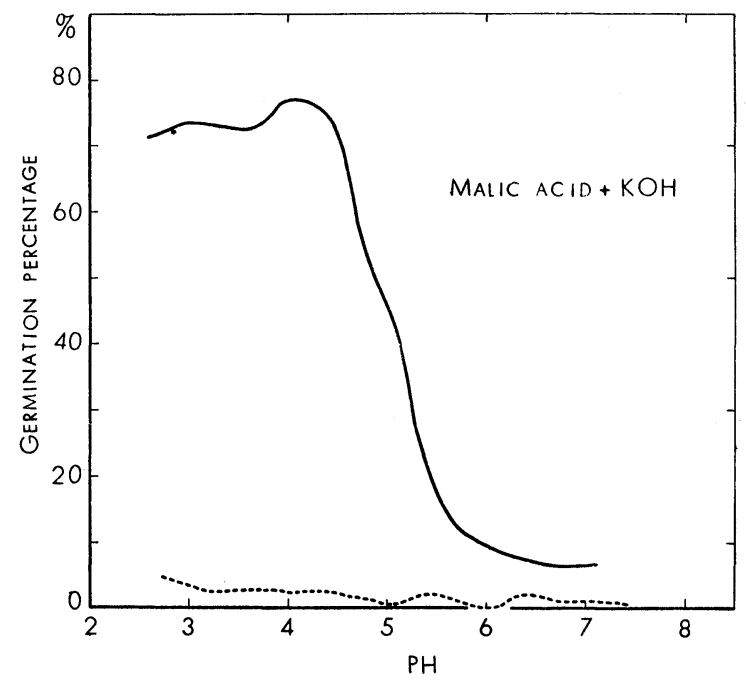

stored tobacco seed is induced even in the absence of gibberellin in the $\mathrm{pH}$ ranges from $\mathrm{pH} 3.8$ to 8.0. The highest germination rate is observed at around $\mathrm{pH} 4.8$.

2) The dark germination inducing action of the mixture of malic acid and $\mathrm{NH}_{4}$ $\mathrm{OH}$ in the absence of gibberellin is not observed on the seed having been stored for 27 months.

3) If the value of germination rate induced by the mixture of malic acid and $\mathrm{NH}_{4} \mathrm{OH}$ at each $\mathrm{pH}$ is deduced from the value of the germination rate induced by gibberellin and the mixture at the corresponding $\mathrm{pH}$, the accelerating effect of the mixture of malic acid and $\mathrm{NH}_{4} \mathrm{OH}$ on gibberellin induced dark germination can be determined (Fig. 1). In case of the seed stored for 15 months, the mixtures of malic acid and $\mathrm{NH}_{4} \mathrm{OH}$ accelerate the gibberellin induced dark germination not only in the far acidic $\mathrm{pH}$ ranges but also at $\mathrm{pH} 4.3$ and $\mathrm{pH} 4.9$.

4) In case of the seed having been stored for 27 months, the mixture of malic 
acid and $\mathrm{NH}_{4} \mathrm{OH}$ accelerates remarkably the gibberellin induced dark germination at $\mathrm{pH}$ range from 2.0 to 4.0 , and above $\mathrm{pH} 4.5$, no acceleration was observed.

5) The mixture of malic acid and $\mathrm{KOH}$ does not induce the dark germination; however, it accelerates the gibberellin induced dark germination of tobacco seed of 15 months' storage at acidic $\mathrm{pH}$ ranges from $\mathrm{pH} 2.5$ through 4.5 .

These phenomena, especially 1) and 5), seem to indicate that for the seed germination, especially the germination at $\mathrm{pH}$ around 4.7 , at least two groups of factors are essential, one being represented by a substance probably synthesized from malic acid and $\mathrm{NH}_{4} \mathrm{OH}$. The seeds having the storage length of 15 months have still some amount of gibberellin or gibberellin-like substance in them and retain the ability to synthesize the substance belonging to the second group, so they can germinate when malic acid and $\mathrm{NH}_{4} \mathrm{OH}$ are added to the germination bed. On the contrary, the seeds having been stored 27 months have used up or destroyed already both groups of the substances, and the ability to synthesize the second group of the substance. so they cannot germinate on the germination bed having only one of these two groups of substances. And even when the substances belonging to both groups are added to the germination bed, the seed of long storage length cannot germinate at the $\mathrm{pH}$ range around 4.7 to 5.5 ; germination in the $\mathrm{pH}$ range below 4.0 seemed to depend on some other factors which are common in the tobacco seed.

The mixture of malic acid and $\mathrm{KOH}$, however, has no germination inducing action. But it accelerates the gibberellin induced germination in acidic $\mathrm{pH}$ range. This effect seems to be identical with the effect of the mixture of malic acid and $\mathrm{NH}_{4} \mathrm{OH}$ and the effect of $\mathrm{pH}$, which are adjusted with inorganic base and acid.

\section{Effect of tartaric acid on dark germination:}

Tartaric acid was added to the germination bed with final concentration of $\mathrm{M}$ / 100 in presence and absence of $10 \mathrm{ppm}$ gibberellin. $\mathrm{pH}$ of the germination bed was adjusted with acid and $\mathrm{NH}_{4} \mathrm{OH}$ or $\mathrm{KOH}$. The storage length of the seed used was 15 months. The results of such experiments are shown in Figs. 3 and 4.

From these figures, the following results are observed.

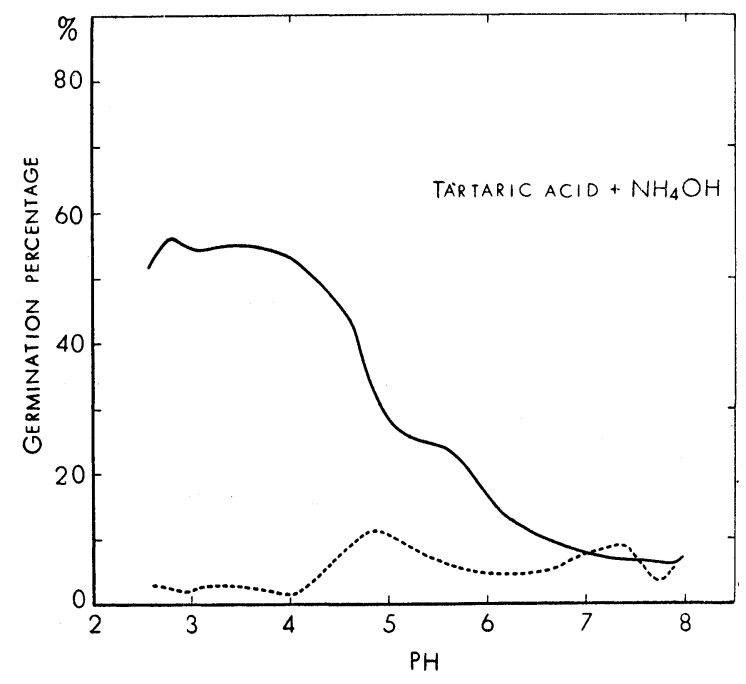

Fig. 3. Effect of tartaric acid on the dark germination of tobacco seed. $\mathrm{pH}$ was adjusted with $\mathrm{NH}_{4} \mathrm{OH}$. - ; 15 months stored seed, in presence of $10 \mathrm{ppm}$ gibberellin, ......; 15 months stored seed, in absence of gibberellin. No dark germination was observed in the control germination beds. 
Fig. 4. Effect of tartaric acid on the dark germination of tobacco seed $\mathrm{pH}$ was adjusted with $\mathrm{KOH}$. —; 15 months stored seed, in presence of $10 \mathrm{ppm}$ gibberellin, ....... 15 months stored seed, in absence of gibberellin. No dark germination was observed on the control germination beds.

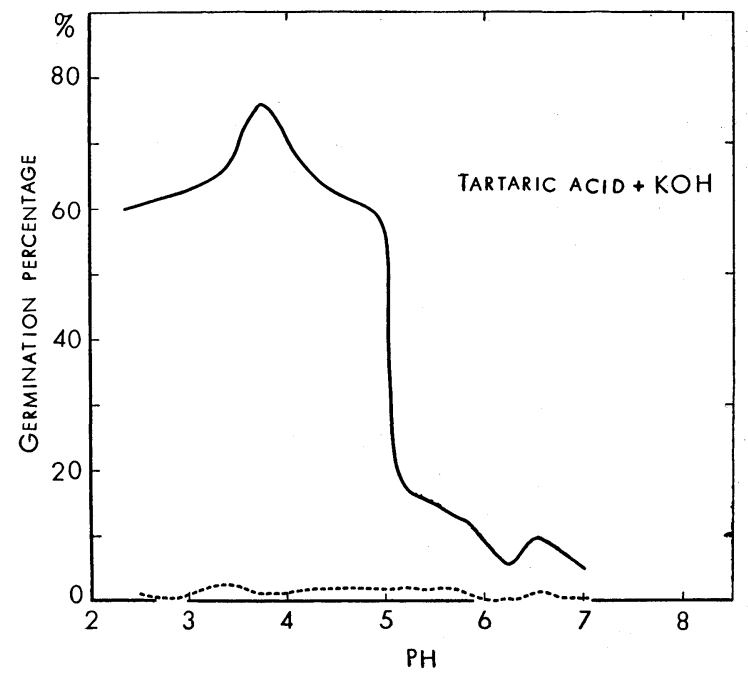

1) The mixture of tartaric acid and $\mathrm{NH}_{4} \mathrm{OH}$ induces the dark germination in the absence of gibberellin in the $\mathrm{pH}$ ranges from 4.5 to 8.0.

2) The highest germination rate is observed at around $\mathrm{pH} 4.8$.

3) The mixture of tartaric acid and $\mathrm{NH}_{4} \mathrm{OH}$ accelerates gibberellin induced dark germination of the seed, not only at acidic $\mathrm{pH}$ ranges below 4.0, but also at around 4.7 .

4) The mixture of tartaric acid and $\mathrm{KOH}$ induces no dark germination, but accelerates the gibberellin induced dark germination from far acidic $\mathrm{pH}$ ranges up to $\mathrm{pH} 4.8$.

5) At $\mathrm{pH} 5.5$, acceleration is observed in both cases.

From these results, considerations similar to those in case of malic acid can be deduced.

Effect of pyruvic, acetic, citric, $\alpha$-ketoglutaric, succinic and fumaric acid on the dark germination:

Ammonium or potassium salts of these acids were added to the germination bed with final concentration of $\mathrm{M} / 100$, in presence and absence of $10 \mathrm{ppm}$ gibberellin. $\mathrm{pH}$ of the germination bed was adjusted to $\mathrm{pH} 4.5$ and 6.0 with these acids and $\mathrm{NH}_{4} \mathrm{OH}$ or KOH. The storage length of the seed used was 15-16 months. The results of these experiments are summarized in Table 1.

From the results of the experiments indicated on the table the followings can be deduced.

1) In the presence of $\mathrm{NH}_{4} \mathrm{OH}$ in the germination bed, any of these acids, except acetic acid and $\alpha$-ketoglutaric acid, induce the dark germination remarkably at $\mathrm{pH}$ 4.5 , but at $\mathrm{pH} 6.0$ this effect is very small.

2) In the case where $\mathrm{KOH}$ is used for $\mathrm{pH}$ adjustment, these acids have almost no germination inducing activities.

3) In the presence of $\mathrm{NH}_{4} \mathrm{OH}$, the organic acids accelerate the gibberellin induced dark germination of the seed remarkably at $\mathrm{pH} 4.5$ but not so remarkably at $\mathrm{pH}$ 6.0. 
Table 1. Effects of organic acids on the dark germination of tobacco seed.

The values in the table indicate the germination percentages at the end of 5 day incubation at $25^{\circ}$. The concentration of the acids and gibberellin is $M / 100$ and 10 ppm, respectively.

\begin{tabular}{|c|c|c|c|c|c|c|c|c|}
\hline \multirow{3}{*}{$\begin{array}{l}\mathrm{pH} \text { adjuster } \\
\mathrm{pH} \\
\text { Gibberellin }\end{array}$} & \multicolumn{4}{|c|}{$\mathrm{NH}_{4} \mathrm{OH}$} & \multicolumn{4}{|c|}{$\mathrm{KOH}$} \\
\hline & \multicolumn{2}{|c|}{4.5} & \multicolumn{2}{|c|}{6.0} & \multicolumn{2}{|c|}{45} & \multicolumn{2}{|c|}{6.0} \\
\hline & - & + & - & + & - & + & - & + \\
\hline Pyruvic & 327 & 54.2 & 0 & 10.1 & 0 & 62.9 & 0 & 3.8 \\
\hline Acetic & 3.9 & 34.0 & 6.5 & 18.8 & 0 & 41.2 & 0 & 5.3 \\
\hline Citric & 15.7 & 85.3 & 8.9 & 25.5 & 2.2 & 76.5 & 0 & 7.3 \\
\hline$\alpha$-ketoglutaric & 1.5 & 47.8 & 0 & 2.3 & 0 & 71.8 & 0 & 19.5 \\
\hline Succinic & 16.0 & 80.0 & 3.7 & 17.5 & 1.4 & 87.0 & 0 & 6.5 \\
\hline Fumaric & 10.8 & 64.1 & 0 & 14.9 & 1.0 & 77.0 & 1.0 & 4.6 \\
\hline Malic & 25.8 & 74.4 & 3.4 & 9.1 & 3.2 & 76.8 & 0 & 8.4 \\
\hline Tartaric & 6.3 & 70.5 & 6.9 & 16.7 & 0 & 23.3 & 0 & 4.2 \\
\hline
\end{tabular}

4) In the presence of $\mathrm{KOH}$, the organic acids accelerate the gibberellin induced dark germination remarkably at $\mathrm{pH} 4.5$ but slightly at $\mathrm{pH} 6.0$.

5) Effectiveness of the germination inducing activities of these organic acids in the presence of $\mathrm{NH}_{4} \mathrm{OH}$ are in the following order at $\mathrm{pH}$ 4.5: pyruvic $>$ malic $>$ succinic $>$ citric $>$ fumaric $>$ tartaric $>$ acetic $>\alpha$-ketoglutaric acid.

6) Effectiveness of the acceleration on the gibberellin induced dark germination of these organic acids are in the following order at $\mathrm{pH} 4.5$, in the presence of $\mathrm{NH}_{4}$ $\mathrm{OH}$ : citric $>$ succinic $>$ malic $>$ tartaric $>$ fumaric $>\alpha$-ketoglutaric $>$ pyruvic $>$ acetic acid.

7) Accelerating effect at $\mathrm{pH} 4.5$ on gibberellin induced dark germination of the acids in the presence of $\mathrm{KOH}$ is larger than that of the corresponding acid in the presence of $\mathrm{NH}_{4} \mathrm{OH}$.

\section{Discussion}

In the experiments using $\mathrm{HCl}-\mathrm{KOH}, \mathrm{HNO}_{3}-\mathrm{KOH}, \mathrm{HCl}-\mathrm{NH}_{4} \mathrm{OH}, \mathrm{H}_{3} \mathrm{PO}_{4}-\mathrm{KOH}$ and $\mathrm{H}_{3} \mathrm{PO}_{4}-\mathrm{NH}_{4} \mathrm{OH}$ as $\mathrm{pH}$ adjusters, Takahashi et al. ${ }^{1,2)}$ reported that these inorganic salts accelerated the gibberellin induced dark germination of tobacco seed in acidic $\mathrm{pH}$ ranges, especially at around 2.0-2.5 and 4.7-5.5 and in case of phosphate, one more specific $\mathrm{pH}$ range at around 4.0 was observed, and in the presence of a nitrogenous compound, the germination was accelerated at around $\mathrm{pH} \mathrm{3.0,} \mathrm{too.} \mathrm{They} \mathrm{also} \mathrm{found}$ that the longer the storage period, the smaller the accelerating effect of these salts at $\mathrm{pH}$ 4.7-5.5, and that these salts fails to induce dark germination of the seed of short storage length.

In the present experiment, the authors found that, in the presence of ammonia or potassium hydroxyde, several carboxylic acids; pyruvic, acetic, succinic, $\alpha$-ketoglutaric, fumaric, malic, and tartartic acid accelerated the gibberellin induced dark germination of tobacco seed in acidic $\mathrm{pH}$ range, especially at around $\mathrm{pH} 2.0$ to 5.0 in case of the short stored seed, and from pH 2.0 to 4.0 in case of long stored seed.

They also found that in the presence of $\mathrm{NH}_{4} \mathrm{OH}$, these acids, with an exception of $\alpha$-ketoglutaric acid, had germination inducing activities through a wide range of 
$\mathrm{pH}$; e. g., from $\mathrm{pH} 3.8$ to 8.0 in case of malic acid, from $\mathrm{pH} 4.5$ to 8.0 in case of tartaric acid. And other acids induce the dark germination at $\mathrm{pH}$ 4.5.

When the seed of short storage length was used as the plant material, malic acid and tartaric acid induced the dark germination mostly around $\mathrm{pH} 4.8$ in the presence of $\mathrm{NH}_{4} \mathrm{OH}$, and these acids accelerated the gibberellin induced dark germination at the same $\mathrm{pH}$. And the facts that other organic acids induced the dark germination and accelerated the gibberellin induced dark germination at $\mathrm{pH} 4.5$ indicate the possibility that other organic acids induce the dark germination mostly at around $\mathrm{pH} 4.7$ and accelerated the gibberellin induced dark germination at the same $\mathrm{pH}$ as inorganic salts accelerated the gibberellin induced germination at around $\mathrm{pH}$ 4.7.

From the same experimental results an accelerating effect of gibberellin on an organic acid induced dark germination was observed in case of the seed of short storage length.

On the contrary when the seed of long storage length was used as the plant material, none of these organic acids induced the dark germination nor accelerated the gibberellin induced dark germination at around $\mathrm{pH} 4.7$.

These results seem to indicate that for the dark germination of the seed, especially the germination at $\mathrm{pH}$ around 4.7 , at least two groups of substances are essential, one being represented by a substance probably synthesized from an organic acid and $\mathrm{NH}_{4} \mathrm{OH}$, the other is gibberellin or gibberellin-like substance. The seed having been stored for a short period have some amount of gibberellin or gibberellinlike substance and maintains the ability to synthesize the substance necessary for germination from an organic acid and $\mathrm{NH}_{4} \mathrm{OH}$. The seed having been stored for a long period, however, loses gibberellin-like substance, and the ability to synthesize the substance in question.

Further discussion about the mechanism of gibberellin induced dark germination of tobacco seed is difficult before we find the presence of the substance in question and determine the exact condition of germination and the age of the seed used.

\section{Summary}

1) Effects on gibberellin induced dark germination of tobacco seed of pyruvic, acetic, citric, $\alpha$-ketoglutaric, succinic, fumaric, malic and tartaric acids were examined in presence of $\mathrm{NH}_{4} \mathrm{OH}$ or $\mathrm{KOH}$.

2) These acids accelerated the gibberellin action at acidic $\mathrm{pH}$ range, especially from $\mathrm{pH} 2.0$ through 4.5. But when the seed of short storage length was used as the material, these acids accelerated the gibberellin induced dark germination at around

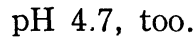

3) Effects of these acids on dark germination of tobacco seed were studied in the presence of $\mathrm{NH}_{4} \mathrm{OH}$ or $\mathrm{KOH}$.

4) Malic and tartartic acids induced dark germination in a wide $\mathrm{pH}$ range in the presence of $\mathrm{NH}_{4} \mathrm{OH}$. The highest germination rate was observed at around $\mathrm{pH} 4.8$.

5) Pyruvic, acetic, citric, succinic and fumaric acids induced the dark germination at $\mathrm{pH} 4.5$ in the presence of $\mathrm{NH}_{4} \mathrm{OH}$. These acids seemed to induce the dark germination mostly at around $\mathrm{pH} 4.8$.

6) The seed of short storage length seemed to have the ability to synthesize some compounds necessary for the induction of dark germination from an organic acid and $\mathrm{NH}_{4} \mathrm{OH}$ at around $\mathrm{pH} 4.8$. 


\section{References}

1) Takahashi, N., Yamada, T., Hashimoto, T., and Yamaki, T., Bot. Mag. Tokyo 75: 49 (1962). 2) Takahashi, N., Moroo, T., Yamada, T., and Yamaki, T., Bot. Mag. Tokyo, 75: 83 (1962), 3) Hashimoto, T., and Yamaki, T., Plant and Cell Physiol. 3 (in press). 4) Hashimoto, T., Plant and Cell Physiol. 2: 463 (1961).

\section{摘要 \\ 高橋憲子*.師尾武子*. 橋本 徹**.八巻敏雄***：タバコ種子の暗発芽に 対する有機酸の影響}

ブライトイエロー種タバコ種子の隌発芽に対する有機酸の影響を $M / 100$ の濃度で発芽床に与えられた ピルビン酸, 酢酸, クエン酸, $\alpha$-ケトグルタル酸, コハク酸, リンゴ酸, 酒石酸などの $\mathrm{pH}$ を $\mathrm{NH}_{4} \mathrm{OH}$, $\mathrm{KOH}$ で $\mathrm{pH} 0.2$ 間隔で調整することによって検討した。実験の範围では酡酸と $\alpha$-ケトグルタル酸を除き 他の酸は $\mathrm{NH}_{4} \mathrm{OH}$ で $\mathrm{pH}$ を調整された場合に，かなり広い $\mathrm{pH}$ 域にわたって暗発芽をひき呿こす，その 最適 $\mathrm{pH}$ は 4.7 附近である。これらの酸はまた，それ自体では発芽を起こさせることのない濃度のジべ レリンと共存させられることによって, $\mathrm{pH} 4.0$ より酸性の域で顕著な発芽をひさすが，それととるに $\mathrm{pH}$ 4.7 附近でもこうした作用が認められる。 また $\mathrm{pH} 4.7$ での有機酸と $\mathrm{NH}_{4} \mathrm{OH}$ とによってひき物こされ る暗発芽は，貯蔵期間の長い種子では次第に低くなり，ついにはジベレリンを共存させても発芽しなくな る.これらのことからこの $\mathrm{pH}$ に括ける暗発芽に注目をした。 この $\mathrm{pH}$ 域に挌ける暗発芽には有機酸と $\mathrm{NH}_{4} \mathrm{OH}$ とから合成されると思われる物質と, ジベレリンによって代用される物質とが必要であり，貯蔵 期間の短いものではこの両物質ともかなり（暗発芽を物こすには少し不足）の量で含まれて物り，わずか 補給するこにより発芽が招こると推察する。この場合ジベレリン様物質の不足の程度はやや軽微であり, 有機酸と $\mathrm{NH}_{4} \mathrm{OH}$ が与穴られれば, 種子中に残存する合成機能が発揮され必要な物質がつくられ, 発芽が 括こるが，貯蔵期間が長くなると発芽に必要な両物質の不足が大きくなり，また合成能の低下に伴ってジ ベレリンも補給する必要が生じ，さらには有機酸と $\mathrm{NH}_{4} \mathrm{OH}$ 特よびジベレリンを与兄ても発芽が起こらな くなることが考㝋られる。（*日本女子大学生理学教室, **武蔵大学生物学教室, *** 東京大学教養学部 生物学教室) 